\title{
The expression and detection of MHC class I antigens on murine neuroblastoma and ependymoblastoma lines
}

\author{
Jenny Pan-Yun Ting, Masafumi Takiguchi, Mary Macchi \\ and Jeffrey A. Frelinger \\ Department of Microbiology and Immunology, and the Lineberger Cancer Research Center, \\ University of North Carolina Medical School, Chapel Hill, NC 27514, U.S.A.
}

(Received 29 April 1986)

(Revised, received 28 July 1986 )

(Accepted 28 July 1986)

Key words: $\begin{aligned} & \text { Major histocompatibility complex antigen, class I; Expression; Detection; Neuroblastoma, } \\ & \text { murine; Ependymoblastoma, murine }\end{aligned}$

\section{Summary}

It has been reported that human neuroblastoma lines are almost devoid of class I transplantation antigens, while human glioma lines express these antigens. Other studies have also shown a paucity of class I antigens on the murine neuroblastoma line N2A, and the expression of these antigens by the murine ependymoblastoma G26 lines. Such differences might represent heterogeneity in class I antigen expression by different brain cell types, and the importance of this to the immunology of the brain prompted us to re-examine class I expression by these cell lines in more detail. Using an exhaustive number of approaches, we were not able to detect significant differences in class I surface antigen expression between N2A and the G26 lines. We compared the murine neuroblastoma line $\mathrm{Cl} 300$ and its cloned derivative, N2A, to the lines G26-20 and G26-24. Antibody-dependent, complement-mediated cytotoxicity revealed detectable levels of both $K$ and $D$ region antigens on these lines. Immunocytofluorometric analysis further confirmed that these lines express high levels of class I antigens, although due to their large sizes,

Address for correspondence: Jeffrey A. Frelinger, Department of Microbiology and Immunology, University of North Carolina at Chapel Hill, 804 FLOB 231H, Chapel Hill, NC 27514, U.S.A. 
the surface densities of class I antigens on these cells are lower than splenocytes. This lower density of class I molecules did not impede the capacity of either the neuroblastoma or the G26 lines to serve as targets of H-2K- or D-specific $T$ effectors. Finally, comparison of these two cell types for class I RNA transcripts also revealed no difference. Thus, our findings which are the most detailed study of these lines are drastically different from findings in humans as well as earlier findings in the murine system. Likely explanations are discussed and precautions are given for the study of class I antigen expression by these lines.

\section{Introduction}

The mouse H-2 major histocompatibility complex (MHC) encodes three families of gene products: the class I transplantation antigens, the class II immune response-associated (Ia) antigens, and the class III complement components (Klein 1975). The class I transplantation antigens are the main molecules recognized by cytotoxic T lymphocytes (reviewed in Zinkernagel and Doherty 1979). They have a wide tissue distribution, and are detected on almost all tissues (Klein 1975). However, their levels of expression vary widely among the different tissues. The CNS as a whole seem to bear a low level of class I antigens as evidenced by the poor ability of homogenized brain tissues to absorb anti-K or $-D$ reactivity (Schachner and Sidman 1973). We showed by immunoprecipitation that cultures of dissociated mouse brains synthesize detectable but very low levels of class I antigens (Ting et al. 1981). More recently, studies of human cell lines showed only very low levels of class I transplantation antigens on neuroblastoma lines (Lampson et al. 1983; Lampson and Fisher 1984; Main et al. 1985), while other studies showed the expression of class I antigens on glioma lines (Wikstrand et al. 1985). A study of a mouse neuroblastoma line also showed that it does not express significant levels of class I antigens (Wong et al. 1984). Other earlier experiments using classical serologic approaches (Joseph and Oldstone 1974) showed evidence of class I expression on $\mathrm{Cl} 300$. Further evidence suggested that $\mathrm{Cl} 300$ could be killed by K-specific cytotoxic lymphocytes (Imamura and Martin 1982). The earlier experiments might have been explained, at least in part, by contaminating antibodies (e.g. anti-gp70 in the alloantiserum used, Wettstein et al. 1975). The experiments reported by Wong et al. suggest several interesting possibilities: (1) the lack of class I antigens on neuroblastomas may provide a mechanism for these tumors to escape immune surveillance, (2) independent of their role as a model for neurons, neuroblastoma lines may represent a system to examine the negative regulation of class I genes, and (3) brain-derived lines of different cellular origin may be heterogeneous with respect to class I antigen expression. Because the studies in the murine system (Wong et al. 1984) were based on a single assay, cytofluorometry, we have re-examined the expression of class $I$ antigens on murine brain cell lines to determine if these observations in humans can be generalized to other species. In contrast to earlier findings in humans as well as mice, our result showed that class I antigens are equally expressed by murine neuroblastoma and glioblastoma lines, 
TABLE 1

MONOCLONAL ANTIBODIES AND ANTISERA SPECIFICITIES

\begin{tabular}{lll}
\hline Monoclonal antibodies antisera & Specificities & References \\
\hline $7-16.4$ & $\mathrm{~K}^{\mathrm{p}} \mathrm{K}^{\mathrm{f}}$ & Harmon et al. 1983 \\
$7-16.32$ & $\mathrm{~K}^{\mathrm{k}}$ & ibid. \\
$34-1-2$ & $\mathrm{D}^{\mathrm{d}}$ & Ozato et al. 1982 \\
$(\mathrm{B} 10 . \mathrm{A}(5 \mathrm{R}) \times$ LP.RIII)F1 anti-B10 & $\mathrm{D}^{\mathrm{b}}$ & NIAID Reference serum, D-2 \\
$(\mathrm{B} 10 . \mathrm{A} \times \mathrm{A} / \mathrm{J})$ anti-AQR & $\mathrm{K}^{\mathrm{q}}$ & \\
A.TL anti-A.AL & $\mathrm{K}^{\mathrm{k}}$ & \\
$(\mathrm{A} \times \mathrm{B} 10 . \mathrm{D} 2)$ anti-B10.A $(5 \mathrm{R})$ & $\mathrm{K}^{\mathrm{b}} \mathrm{I}^{\mathrm{b}}$ & \\
\hline
\end{tabular}

and they are functionally recognized as target antigens by cytotoxic $T$ cells. Thus, the generally held view that all neuroblastoma cells do not express class I antigens or express low levels of these determinants should be re-evaluated.

\section{Materials and Methods}

Mice

All mice were bred in our mouse facilities at the University of Southern California, Los Angeles, CA or the University of North Carolina, Chapel Hill, NC.

\section{Antibodies}

Conventional alloantisera were produced by repeated immunization of appropriate recipient mice with a combination of spleen, thymus and lymph node cells as described (David et al. 1973). Alloantisera were characterized by cytotoxicity testing on lymph node cells from inbred and recombinant animals prior to use. Monoclonal antibodies have been previously characterized as described (Harmon et al. 1983). The alloantisera and monoclonal antibodies used are shown in Table 1.

\section{Plasmid}

The plasmid pH-2IIa (provided by Dr. Leroy Hood, Caltech, Pasadena, CA) which contains class I cDNA sequences has been described (Steinmetz et al. 1981).

\section{Cell lines}

G26 is a cell line derived from a C57BL/6 mouse tumor originally described ependymoblastoma (Zimmerman 1955). G26-20 and G26-24 are clonal lines derived from the G26 parent line (Sundarray et al. 1975). Cl300 is a neuroblastoma line derived from an $\mathrm{A} / \mathrm{J}$ mouse. Neuro-2A (N2A) is a clonal derivative of $\mathrm{Cl} 300$. F9 is an embryonal carcinoma line that does not express class I transcripts (Morello et al. 1982). All three were obtained from the American Tissue Culture Collection 
(ATCC). F12 cells are C3H-derived $\mathrm{L}$ cells transfected with and expressing the $\mathrm{D}^{p}$ gene (Macchi et al. 1984).

Antibody-mediated, complement-dependent microcytotoxicity assay

The dye exclusion microcytotoxicity assay was performed as previously described (David et al. 1973; Fleming et al. 1983). 1000 cells in $2 \mu \mathrm{l}$ were incubated with the appropriate antibody for $15 \mathrm{~min}$ in a Terasaki tray. The antibody was removed, and replaced with $2 \mu 1$ of rabbit complement. After a 30 min incubation at $37^{\circ} \mathrm{C}$, the cells were fixed with formaldehyde, and viability determined by phase-contrast microscopy.

\section{Biosynthetic labeling and immunoprecipitation}

Splenic and G26 cells were prepared and labeled as previously described (Ting et al. 1981). $20 \times 10^{6}$ cells were radiolabeled with $\left[{ }^{3} \mathrm{H}\right]$ tyrosine and $\left[{ }^{3} \mathrm{H}\right] l$ leucine and extracted with NP-40. Extracts were immunoprecipitated with the appropriate antibody and protein A-bearing Staphylococcus aureus (Cowan I strain), and electrophoresed on a one-dimensional SDS polyacrylamide gel (Laemmli 1970).

\section{Cytofluorometric analysis}

Fluorescence labeling of cells and cytofluorometric analysis were performed on a Coulter Epics V System. Quantitative determination of surface density was analyzed with the Immunoprogram for the Coulter Epics V System. Since all antibodies were used at saturating concentrations, fluorescence is proportional to antigen amount. The immunoprogram relates light scatter as a measure of cell size to amount of dye bound.

\section{Cell-mediated lympholysis}

Effector lymphocytes for cell-mediated lympholysis (CML) assays were prepared as previously described (Hirschberg et al. 1977; Wettstein and Frelinger 1980). In brief, $3 \times 10^{6} / \mathrm{ml}$ lymph node cells were incubated with $3 \times 10^{6} / \mathrm{ml} \mathrm{X}$-irradiated splenocytes in a mixed lymphocyte culture for 4 days. Targets were radiolabeled with $\mathrm{Na}^{51} \mathrm{CrO}_{4}$, washed and resuspended at $10^{5}$ cells $/ \mathrm{ml}$ of medium. $100 \mu \mathrm{l}$ of target cells were incubated with varying concentrations of effectors for $4 \mathrm{~h}$, and the supernatant fluid was collected and counted. Results are expressed as follows:

\% ${ }^{51} \mathrm{Cr}$ release $=\frac{\text { Counts released in experimental }- \text { spontaneous release }}{\text { Total releasable counts }- \text { spontaneous release }} \times 100 \%$

\section{RNA isolation and dot-blot analysis}

RNA was isolated by a published procedure using guanidine-isothiocyanate/cesium chloride gradients (Glisin et al. 1974). The RNA was quantitated by dot-blot analysis. Briefly, RNA was denatured in glyoxal as described (McMaster and Carmichael 1977). Serial dilutions of the RNA were applied on nitrocellulose paper using a minifold (Schleicher and Schuell, Keene, NH, U.S.A.), and then hybridized to ${ }^{32} \mathrm{P}$-labeled $\mathrm{pH}-2 \mathrm{IIa}$. 


\section{Results}

Detection of class I transplantation antigens on murine neuroblastoma and glioma lines by antibody-dependent complement-mediated lysis

We first examined the expression of $\mathrm{H}-2 \mathrm{~K}$ and $\mathrm{D}$ antigens by murine neuroblastoma and G26 lines using antibody-dependent, complement-mediated lysis. Since N2A is a clone of $\mathrm{Cl} 300$ which was itself derived from an $\mathrm{A} / \mathbf{J}$ mouse, $\mathrm{H}$-2-identical B10.A splenocytes which express $\mathrm{K}^{\mathbf{k}}$ and $\mathrm{D}^{\mathbf{d}}$ antigens were used as a positive control. Treatment of B10.A splenocytes with monoclonal antibodies against $\mathrm{K}^{\mathrm{k}}$ (mAb 7-16.32) and $\mathrm{D}^{\mathrm{d}}$ (mAb 34-1-2) resulted in the expected lysis of nearly $100 \%$ of the cells at high concentrations (Fig. $1 \mathrm{~A}$ and $\mathrm{B}$ ). The negative control $\mathrm{mAb}$, 7-16.4, did not lyse the splenocytes. When N2A was treated with the same mAbs, lysis occurred only in the presence of high concentrations of antibody. The anti- $\mathrm{D}^{\mathrm{d}}$ $\mathrm{mAb}$ at an $1: 10$ dilution lysed $20 \%$ of the cells while the anti- $\mathrm{K}^{\mathrm{k}} \mathrm{mAb}$ at an $1: 10$ dilution lysed $50 \%$ of the cells. These results suggest that N2A expresses low although detectable amounts of $\mathrm{K}^{\mathrm{k}}$ and $\mathrm{D}^{\mathrm{d}}$ antigens. The difference between the $\mathrm{K}$ and $\mathrm{D}$ region antigens expressed is not detected by cytofluorometry, and therefore may not represent real differences in expression (see below). Similar findings were seen using $\mathrm{Cl} 300$ (data not shown).

When we used the G26 as target cells in the antibody-dependent, complementmediated microcytotoxicity assay, we observed similar results (Fig. 1C and D). 37\% of $\mathrm{G} 26-20$ was lysed by anti-K $\mathrm{K}^{\mathrm{b}}$ antiserum and $50 \%$ of $\mathrm{G} 26-20$ was lysed by anti-H-2D ${ }^{b}$ antiserum. Similar results were obtained for G26-24 (data not shown).

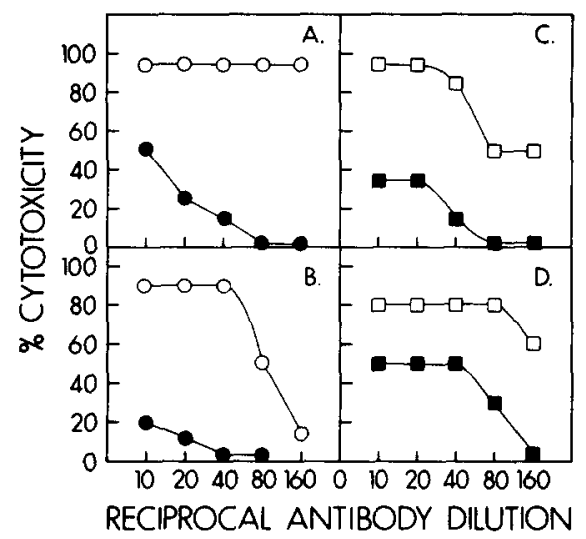

Fig. 1. Cytolysis of $\mathrm{N} 2 \mathrm{~A}$ and $\mathrm{G} 26-20$ by $\mathrm{H}-2$-specific antibody and complement. The microcytotoxicity assays were performed as described in Materials and Methods. The symbol $(\mathrm{O}-\mathrm{O})$ represents B10.A splenocytes; $(-\bullet)$, N2A cells; ( $\square-\square)$, B10 splenocytes; $(\square-\square)$, G26-20 cells. Antibodies used in panels $A-D$ are specific for $\mathrm{K}^{\mathrm{k}}(\mathrm{mAb} 7-16.32), \mathrm{D}^{\mathrm{d}}$ (mAb 34-1-2), $\mathrm{K}^{\mathrm{b}} \mathrm{I}^{\mathrm{b}}[(\mathrm{A} \times \mathrm{B} 10 . \mathrm{D} 2)$ anti-B10.A(5R)], and $\mathrm{D}^{\mathrm{b}}$ (N.I.H. leucocyte typing antiserum D-2). Spontaneous lysis in the presence of an irrelevant mouse serum (anti-K $\mathrm{K}^{\mathrm{q}}$ ) or irrelevant mAb (anti-K $\mathrm{K}^{\mathrm{p}} \mathrm{K}^{\mathrm{f}}$ ) has been subtracted from all the values. 


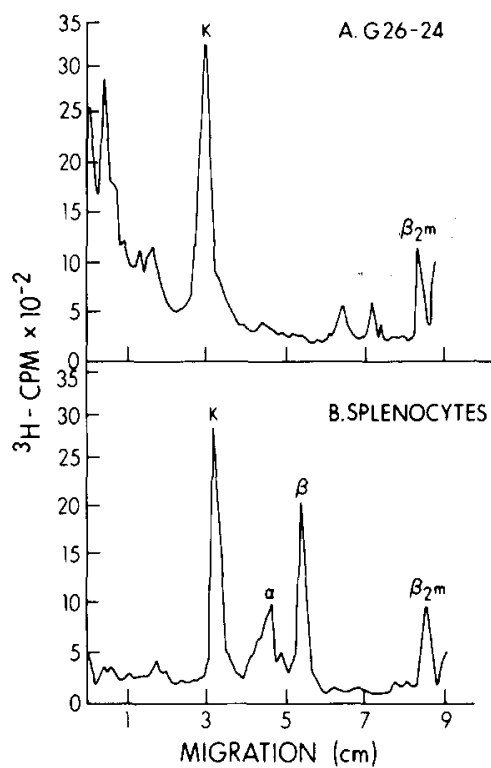

Fig. 2. SDS acrylamide gel electrophoresis patterns of $\mathrm{K}$ and/or I-A molecules isolated from G26-24 cells and splenocytes. G26-24 and (B6×A)F1 splenic lysates were immunoprecipitated with [(B10.D2 $\times$ A)F1 anti-B10.A(5R)] followed by fixed Staphylococcus aureus, Cowan I strain. Panel $A, \mathrm{H}-2 \mathrm{~K}^{\mathrm{b}}$ heavy chain and $\beta_{2} \mathrm{M}$ isolated from $\mathrm{G} 26-24$. Panel $B, \mathrm{H}-2 \mathrm{~K}^{\mathrm{b}}$ heavy chain, I-A heavy and light chains, and $\beta_{2} \mathrm{M}$ from spleen cells.

These figures agree with published data on other G26 subclones (Sundarray et al. 1975).

Since the antiserum against $\mathrm{K}^{\mathrm{b}}$ contains anti-Ia reactivity, it was important to determine if the lysis of G26 cells may be partially or completely due to anti-Ia reactivity. This is of special interest due to the expression of Ia on some glial cells (Ting et al. 1981; Hausser et al. 1983; Fontana et al. 1984) and human glioma lines (Carrel et al. 1982; Takiguchi et al. 1985; Wikstrand et al. 1985). To examine this possibility, we resorted to immunoprecipitation and SDS gel electrophoresis. Fig. 2 shows the SDS acrylamide gel analysis of G26-24 extracts immunoprecipitated with an anti- $\mathrm{K}^{\mathrm{b}} \mathrm{I}^{\mathrm{b}}$ reagent $[(\mathrm{A} \times \mathrm{B} 10 . \mathrm{D} 2)$ anti-B10.A $(5 \mathrm{R})] .(\mathrm{B} 6 \times \mathrm{A}) \mathrm{F} 1$ spleen extract was run in parallel as a positive control. When the glial cell lysate was treated with this serum, a peak of approximately $45000 \mathrm{Da}$ that comigrated with splenic $\mathrm{K}^{\mathrm{b}}$ was obtained. A peak of approximately $12000 \mathrm{Da}$ which presumably represents $\beta_{2}$ microglobulin was detected in both extracts. The alloantiserum also contains anti-class II reactivity, which precipitated molecular species of 31000 and $28000 \mathrm{Da}$ from the spleen cell lysate but not the G26 extracts (Ting et al. 1981). These species represent the $\alpha$ - and $\beta$-subunits of Ia antigens. This result showed that G26-24 cells express class I but not class II molecules.

Detection of class I antigens by cytofluorometry

Because the antibody-dependent complement-mediated lysis is not a quantitative 
TABLE 2

CYTOFLUOROMETRIC ANALYSIS OF N2A, Cl300 AND G26-20

\begin{tabular}{lllll}
\hline $\begin{array}{l}\text { H-2 antigen } \\
\text { examined }\end{array}$ & Cell & $\begin{array}{l}\text { Mean } \\
\text { fluorescence }\end{array}$ & $\begin{array}{l}\text { Mean size } \\
\text { (channel No.) }\end{array}$ & $\begin{array}{l}\text { Surface } \\
\text { density }\end{array}$ \\
\hline $\mathrm{K}^{\mathbf{k}}$ & N2A & 6.6 & 556 & $0.212(46 \%)^{\text {a.b }}$ \\
& C1300 & 3.9 & 473 & $0.172(37 \%)$ \\
& B10.A splenocytes & 1.8 & 199 & $0.460(100 \%)$ \\
$\mathrm{D}^{\mathrm{d}}$ & N2A & 8.6 & 556 & $0.278(32 \%)$ \\
& C1300 & 5.3 & 473 & $0.237(28 \%)$ \\
& B10.A splenocytes & 3.4 & 199 & $0.860(100 \%)$ \\
$\mathrm{K}^{b}$ & G26-20 & 3.5 & 499 & $0.138(30 \%)$ \\
& C57BL/10 splenocytes & 2.1 & 214 & $0.465(100 \%)$ \\
$\mathrm{D}^{\mathrm{b}}$ & G26-20 & 5.3 & 499 & $0.214(27 \%)$ \\
& C57BL $/ 10$ splenocytes & 3.7 & 214 & $0.799(100 \%)$ \\
\hline
\end{tabular}

a Density $=$ mean intensity $\times 10^{4} / \mathrm{size}^{2}$, calculated according to the Immunoprogram for the Coulter Epics V System.

b Percent $=\frac{\text { Surface density of N2A, C1300 or G26-20 }}{\text { Surface density of control splenocytes }}$

procedure, we subjected the neuroblastoma and G26 lines to cytofluorometric analysis (Table 2). In all these experiments, optimal concentrations of antibodies were used. All experiments were reproduced by two investigators independently. In addition, N2A and $\mathrm{Cl} 300$ were used immediately after arrival from ATCC. In general, our findings showed that the $\mathrm{Cl} 300, \mathrm{~N} 2 \mathrm{~A}$ and G26-20 cells all express more total class I antigens than splenocytes. However, the surface densities of class I antigens on these brain-derived lines are lower than that of splenocytes due to differences in cell sizes. Both N2A and G26-20 are 2-3 times larger than splenocytes as determined by their scatter profiles. Such differences in size and surface antigen densities may explain why the N2A cells require higher concentrations of monoclonal antibodies than splenocytes for lysis in an earlier experiment (Fig. 1). This explanation is in accord with our observations that false-negative readings by microcytotoxicity assays were obtained with low concentrations of anti-K or -D reagents (unpublished observation).

Detection of class I antigens by cytotoxic $T$ cells

The previous two methods relied on detection by the binding of antibody molecules to cell surface antigens. We show here that the class I antigens on the neuroblastoma and G26 lines are also recognized by cytotoxic $T$ effector cells. We first analyzed $\mathrm{N} 2 \mathrm{~A}$ for killing by anti- $\mathrm{K}^{\mathrm{k}}$ - and $-\mathrm{D}^{\mathrm{d}}$-specific cytotoxic $\mathrm{T}$ cells (Fig. 3 ). In the first experiment, B10.A cells were used to stimulate B10.D2 effectors. The effectors thus generated recognize the $K^{k}$ region products expressed by $N 2 A$. These anti-K $\mathbf{K}^{\mathbf{k}}$-specific effectors incubated with ${ }^{51} \mathrm{Cr}$-labeled N2A cells resulted in a $62 \%$ specific lysis at an effector: target ratio of $100: 1$. Similarly, anti- $\mathrm{D}^{\mathrm{d}}$ effectors $(\mathrm{C} 3 \mathrm{H}$ 


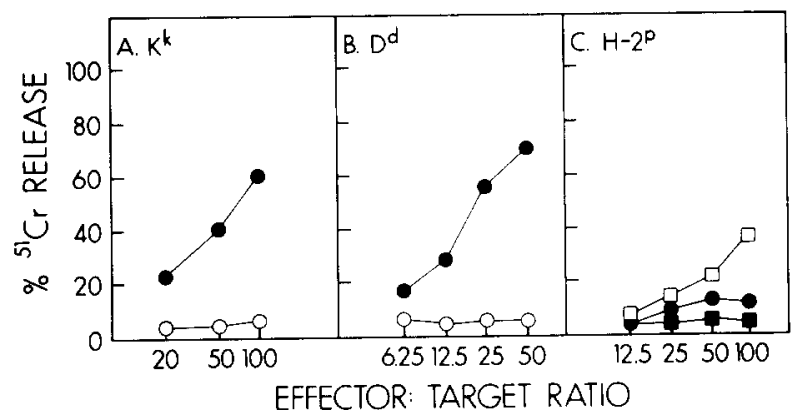

Fig. 3. H-2-specific lysis of N2A in CML. Cytotoxic T effectors with reactivities against $K^{k}, D^{d}$ and $\mathrm{H}-2^{p}$ were used to lyse N2A $(\bullet)$ and controls. The controls include $\mathrm{G} 26-20\left(\mathrm{O}, \mathrm{H}-2^{\mathrm{b}}\right), \mathrm{F} 12(\square, \mathrm{L}$ cells transfected with a $D^{p}$ gene, Macchi et al. 1984), and L cells $\left(\square, H-2^{k}\right)$. Effectors in panels $A-C$ are respectively generated as follows: B10.D2 anti-B10.A, C3H anti-B10.A, and B10.A anti-B10.P.

anti-B10.A) incubated with ${ }^{51} \mathrm{Cr}$-labeled N2A cells resulted in a $65 \%$ specific lysis. In both experiments, incubation with the negative control targets, G26-20, did not result in significant ${ }^{51} \mathrm{Cr}$-release. Thus $\mathrm{N} 2 \mathrm{~A}$ is clearly lysed by $\mathrm{T}$ effector cells.

Because of a recent report that human neuroblastoma lines are not lysed by HLA-specific $\mathrm{T}$ effectors, but are most probably lysed by natural killer cells in a typical CML assay, it was critical to show that the observed killing was not due to H-2-nonspecific NK cells (Main et al. 1985). This control is shown in Fig. 3C. B10.A anti-B10.P T effector cells did not lyse N2A but did lyse F12 ( ${ }^{p}$ gene-transfected L cells) (Macchi et al. 1984). Therefore the killer activity is unlikely attributed to NK activity, which is by definition $\mathrm{H}-2$-nonspecific.

CML assays also showed that cytotoxic $\mathrm{T}$ cells recognize class $\mathrm{I}$ antigens expressed by G26-24. Effectors generated against whole H-2 difference (B10.K

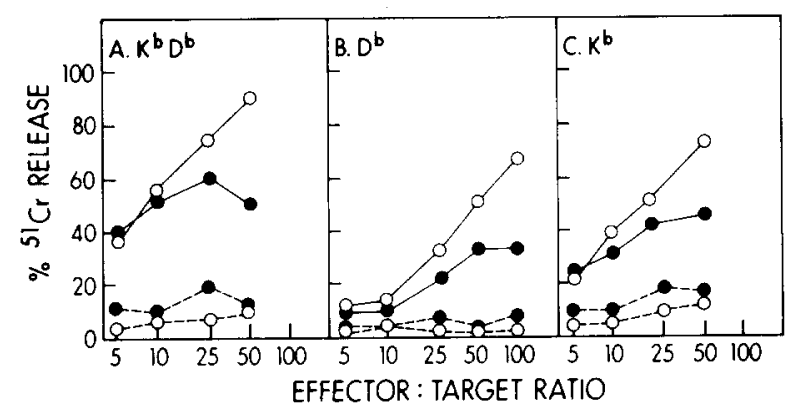

Fig. 4. H-2-specific lysis of G26-24 in CML. Cytotoxic $T$ effectors with reactivities again $K^{b}$ and/or $D^{b}$ region products were used to lyse G26-24 cells $(\mathrm{O}-\mathrm{O})$ ) and $\mathrm{B} 10$ splenocytes $(\bullet-\bullet)$ respectively. Negative controls consist of irrelevant effectors incubated with $\mathrm{G} 26-24$ and $\mathrm{B} 10$ cells $((\mathrm{O}-\mathrm{O})$ and (-)) respectively. Panel $A$ : effector $\mathrm{T}$ cells were B10.K anti-B10. Negative control effectors were B10.S anti-B10.K. Panel $B$ : effector $T$ cells, B10.A anti-B10.A(1R); negative controls, B10.A anti-B10.K. Panel $C$ : effector T cells, B10.A anti-B10.A(5R); negative controls, B10.A anti-B10.K. 


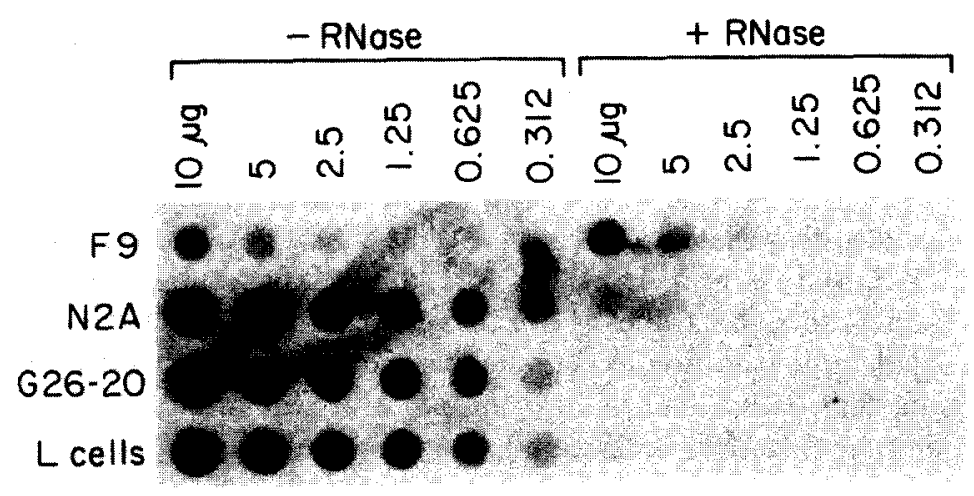

Fig. 5. Equal levels of class I/class I-like transcripts are present in N2A and G26-20 cells. A dot-blot of serially diluted RNA was performed as described in Materials and Methods. ${ }^{32} \mathrm{P}$-labeled pH-2IIa was used as the hybridization probe. Samples in the right half of the blot were treated with DNase-free RNase prior to application.

anti-B10) resulted in $89 \%$ lysis of the G26 at an effector to target ratio of $50: 1$ (Fig. 4). When effectors against an irrelevant H-2 haplotype (B10.S anti-B10.K),were incubated with the G26 cells, very low specific lysis was observed (3-10\%).

Similarly, $\mathrm{K}^{\mathrm{b}}$-specific effectors [B10.A anti-B10.A(5R)] and $\mathrm{D}^{\mathrm{b}}$-specific [B10.A anti-B10.A(1R)] effectors resulted in $74 \%$ and $68 \%$ specific lysis respectively. The appropriate negative control cells did not result in significant lysis of the cells. Similar results were obtained with G26-20. These experiments indicate that N2A and $\mathrm{G} 26$ are efficiently recognized by cytolytic $T$ cells.

Detection of class I transcripts by dot-blot analysis

As a final confirmation that N2A and G26 express similar amounts of class I determinants, RNA was isolated from these cells, and hybridized to pH-2IIa, a MHC class I gene probe (Steinmetz et al. 1981). As shown in Fig. 5, RNA from N2A and G26-20 hybridized to nick-translated pH-2IIa equally well. RNA from F9, which does not express class I determinants produced only a weak signal (Morello et al. 1982). This is probably due to DNA contamination since treatment of the F9 sample with DNase-free RNase did not remove the signal. In contrast, RNase treatment of RNA from N2A, G26-20 and L cells completely removed the hybridization signal, indicating signals observed in these samples were due to RNA. Thus, N2A and G26-20 express similar quantities of class I-related RNA transcripts. A separate experiment revealed equal levels of class I transcripts in $\mathrm{Cl} 300$ (data not shown).

\section{Discussion}

Our results indicate that the murine neuroblastoma lines N2A and C1300 and the glioblastoma lines of the G26 series express nearly equal quantities of class I 
transplantation antigens. This report represents a detailed study of class I antigen/gene expression by these lines since four different assays were utilized. Our results unequivocally show the presence of fairly high quantities of class I antigens and transcripts on $\mathrm{N} 2 \mathrm{~A}$ and $\mathrm{Cl} 300$.

Our results are of interest for several reasons. First, our data is in contrast with studies of human neuroblastomas that showed a paucity of class I antigens on these cells (Lampson et al. 1983; Main et al. 1985). Therefore, the lack or near-absence of class I determinants on neuroblastoma lines is not universal. Although Lampson et al. (1983) showed a considerable variation in class I expression, all were significantly lower than most somatic cells. If mechanisms for the negative regulation of class I antigens exist in human neuroblastoma lines, similar mechanisms do not appear to be operable in their murine counterparts.

Second, our result is also in contrast to an earlier study of N2A which showed the paucity of class I antigens as determined by cytofluorometric analysis (Wong et al. 1984). In our hands, the levels of class I antigens/RNA expressed by N2A are significant as determined by several assays, including cytofluorometric analysis, CML and RNA analysis. However, when the cytofluorometric assay is used, it is critical to use a saturating concentration of antibody. In some of our early unpublished experiments, insufficient anti- $\mathrm{H}-2$ antibodies were used, and consequently, N2A appeared to be H-2-negative, while control splenocytes in the same experiment were clearly H-2-positive. When the antibodies were titered on the N2A cells and optimal concentrations of antibodies were used, $\mathrm{H}-2$ antigens were reproducibly detected on $\mathrm{N} 2 \mathrm{~A}$. This may also explain the discrepancy between this report and an earlier one (Wong et al. 1984). Thus, the conclusion that N2A does not express class I determinants should be re-evaluated. $\mathrm{Cl} 300$ was originally isolated as a neuroblastoma in mice. It is possible that the expression of class I on $\mathrm{Cl} 300$ represents the normal level of expression of a relatively rare neuroblast type. Thus it might be that this reflects the cell of origin rather than a species difference between man and mouse.

Finally, our finding that these neuroblastoma and G26 lines serve as efficient targets of cytotoxic $T$ cells strongly suggests that viral infection of these cells may elicit a viral-specific, H-2-restricted cytotoxic $\mathrm{T}$ cell response. Thus, these lines may provide valuable in vitro models/systems for the study of cell-mediated immunity against neurotropic viruses which have limited capacity to grow in other cell types, but can grow in brain-derived lines.

Our report also showed the lack of class II antigens on the G26 lines. The expression of class II antigens on glial cells is of interest because $\mathrm{Ia}^{+}$glial cells have been identified in rodent and human brains (Ting et al. 1981; Hauser et al., 1983). Furthermore, $\gamma$-interferon-treated rodent astrocytes can present antigens to $T$ cells (Fierz et al. 1985; Takiguchi and Frelinger 1986). $\mathrm{DR}^{+}$glioma lines with antigenpresenting capacity have also been identified (Takiguchi et al. 1985). However, only a fraction of the human glioma lines examined appear to express DR antigens in the absence of $\gamma$-IFN induction (Takiguchi et al. 1985). Therefore, it is not unexpected that the $\mathrm{G} 26$ lines are Ia-negative and it is possible that other $\mathrm{Ia}^{+}$murine glioma lines are in existence. 
It is interesting to contrast the expression of class I MHC antigens on $\mathrm{Cl} 300$ and the absence of class I observed on neurons. It is possible that only neuroblasts normally express class $I$. If so, the variable expression on human neuroblastoma might correlate with their relative differentiation state. It would be interesting to test expression of class I in $\mathrm{Cl} 300$ under conditions which favor differentiation into more mature-appearing neuron-like-cells.

\section{Acknowledgements}

This work was supported by the American Cancer Society Research Grant No. IM-367 and the Multiple Sclerosis Grant No. RG1785-A-1 to J.P.-Y. Ting and NIH Grant AI-20288 to J.A. Frelinger, J.P.-Y. Ting is a recipient of the American Cancer Society Junior Faculty Research Award. The authors thank Ms. Jean Holliday for excellent secretarial assistance and Dr. Larry Arnold for the cytofluorometric analysis.

\section{References}

Carrel, S., N. de Tribolet and N. Gross, Expression of HLA-DR and common acute lymphoblastic leukemic antigens on glioma cells, Eur. J. Immunol., 12 (1982) 354-357.

David, C.S., C.D. Shreffler and J.A. Frelinger, New Lymphocyte antigen systems (Lna) controlled by the Ir region of the H-2 gene complex, Proc. Natl. Acad. Sci. U.S.A., 70 (1973) 2509-2511.

Fierz, W., B. Endler, K. Reske, H. Wekerle and A. Fontana, Astrocytes as antigen-presenting cells. I. Induction of Ia antigen expression on astrocytes by $\mathrm{T}$-cells via immune interferon and its effect on antigen presentation, J. Immunol., 134 (1985) 3785-3793.

Fleming, J.O., J.P.-Y. Ting, S.A. Stohlman and L.P. Weiner, Improvements in obtaining and characterizing mouse cerebrospinal fluid: application to mouse hepatitis virus-induced encephalomyelitis, $J$. Neuroimmunol., 4 (1983) 129-140.

Fontana, A., W. Fierz and H. Wekerle, Astrocytes present myelin basic protein to encephalitogenic T-cell lines, Nature, 307 (1984) 273-276.

Glisin, V., R. Crkvenjakov and C. Byus, Ribonucleic acid isolated by cesium chloride centrifugation, Biochemistry, 13 (1974) 2633-2638.

Harmon, R.C., N. Stein and J.A. Frelinger, Monoclonal antibodies reactive with $\mathrm{H}-2$ determinants, Immunogenetics, 18 (1983) 541-545.

Hausser, S.L., A.K. Bhan, F.H. Gilles, C.J. Hoban, E.L. Reinberz, S.T. Schlossman and H.L. Weiner, Immunohistochemical staining of human brain with monoclonal antibodies that identify lymphocytes, monocytes and Ia antigens, J. Neuroimmunol., 5 (1983) 197-205.

Hirschberg, H., H. Skare and E. Thorsby, Cell mediates lympholysis: a microplate technique requiring few target cells and employing a new method of supernatant collection, J. Immunol. Methods, 9 (1977) 251-266.

Imamura, M. and J.W. Martin, Variation in histocompatibility antigen expression of murine tumors. Differences in expression and immunogenicity of $\mathrm{H}-2 \mathrm{~K}$ region-coded unique antigens, J. Immunol, 129 (1982) 877-881.

Joseph, B.S. and M. Oldstone, Expression of selected antigens on the surface of cultured neural cells, Brain Res., 80 (1974) 421-434.

Klein, J., Biology of the Mouse Histocompatibility-2 Complex, Springer-Verlag, New York, 1975.

Laemmli, U.K., Cleavage of structural proteins during the assembly of bacteriophage T4, Nature, 227 (1970) 680-685. 
Lampson. L.A., C.A. Fisher and J.P. Whelan, Striking paucity of HLA-A, B, C and $\mathrm{B}_{2}$ microglobulin on human neuroblastoma cell lines, J. Immunol., 130 (1983) 2471-2478.

Lampson, L.A. and C.A. Fisher, Weak HLA and beta2-microglobulin expression of neuronal cell lines can be modulated by interferon, Proc. Natl. Acad. Sci. U.S.A., 81 (1984) 2471-2478.

Macchi, M.J., J.G. Woodward, E. McLaughlin-Taylor, J. Griffin, L. Hood and J.A. Frelinger, Cloning and identification of the H-2DP gene, Immunogenetics, 19 (1984) 195-204.

Main, E.K., L.A. Lampson, M.K. Hart, J. Kornbluth and D.B. Wilson, Human neuroblastoma lines are susceptible to lysis by natural killer cells but not cytotoxic T lymphocytes, J. Immunol., 135 (1985) 242-246.

McMaster, G.K. and G.G. Carmichael, Analysis of single- and double-stranded nucleic acids on polyacrylamide and agarose gels by using glyoxal and acridine orange, Proc. Natl. Acad. Sci. U.S.A., 74 (1977) 4835-4838.

Morello, D., F. Daniels, P. Balducci, Y. Cayne, G. Gashelin and P. Kourilsky, Absence of significant H-2 and 2-microglobulin mRNA expression by mouse embryonal carcinoma cells, Nature, 296 (1982) $260-262$

Ozato, K., N.M. Mayer and D.H. Sachs, Monoclonal antibodies to mouse major histocompatibility complex antigens. IV. A series of hybridoma clones producing anti-H $-2^{\mathrm{d}}$ antibodies and an examination of expression of $\mathrm{H}_{-2} \mathrm{~d}$ antigens on the surface of these cells, Transplantation, 34 (1982) 113-120.

Schachner, M. and R.L. Sidman, Distribution of H-2 alloantigen in adult and developing mouse brain, Brain Res., 60 (1973) 191-198.

Steinmetz, M., J.G. Frelinger, D. Fisher, T. Hunkapiller, P. Pereira, S. Weissman, H. Uehara, S. Natheson and L. Hood, Three cDNA clones encoding mouse transplantation antigens: homology to immunoglobulin genes, Cell, 24 (1981) 125-134.

Sundarray, N., M. Schaehner and S.G. Pfeiffer, Biochemically differentiated mouse glial cell lines carrying a nervous system specific cell surface antigen (NS-1), Proc. Natl. Acad. Sci. U.S.A., 72 (1975) 1927-1931.

Takiguchi, M. and J.A. Frelinger, Induction of antigen presentation ability in purified cultures of astrocytes by interferon- $\gamma$, J. Mol. Cell. Immunol., 2 (1986) 269-280.

Takiguchi, M., J.P.-Y. Ting. S.S. Buessow, C. Boyer, Y. Gillespie and J.A. Frelinger, Response of glioma cells to interferon-gamma: increase in class II RNA, protein and mixed lymphocyte reaction stimulating activity, Eur. J. Immunol., 19 (1985) 809-814.

Ting, J.P.-Y., B. Shigekawa, D.S. Linthicum, L.P. Weiner and J.A. Frelinger, Expression and synthesis of murine immune response associated (Ia) antigens by brain cells. Proc. Natl. Acad. Sci. U.S.A., 78 (1981) 3170-3174.

Wettstein, P. and J.A. Frelinger, $\mathrm{H}-2$ effects on cell-cell interactions in response to single nor- $\mathrm{H}-2$ antigen. III. Evidence for several Ir gene systems mapping in the $\mathrm{H}-2 \mathrm{~K}$ and $\mathrm{H}-2 \mathrm{D}$ region, Immunogenetics, 10 (1980) 211-225.

Wettstein, P.J., P. Krammer, R.C. Nowinski, C.S. David, J.A. Frelinger and D.C. Shreffler, A cautionary not regarding Ia and H-2 typing of murine lymphoid tumors. Immunogenetics, 3 (1976) 507-516.

Wikstrand, C.J., F.C. Grahmann, R.D. McComb and D.D. Bigner, Antigenic heterogeneity of human anaplastic gliomas and glioma-derived cell lines defined by monoclonal antibodies, J. Neuropathol. Exp. Neurol, 44 (1985) 229-241.

Wong, G.H.W., I. Clark-Lewis, A.W. Harris and J.W. Schrader, Effect of cloned interferon- $\gamma$ on expression of H-2 and Ia antigens on cell lines of hematopoietic, lymphoid, epithelial, fibroblastic and neuronal origin, Eur. J. Immunol., 14 (1984) 52-56.

Zimmerman, H.M., The nature of gliomas as revealed by animal experimentation, Am. J. Pathol.. 31 (1955) 1-29.

Zinkernagel, R.M. and P.C. Doherty, MHC restricted cytotoxic T cells: studies on the biological role of polymorphic major transplantation antigens determining $\mathrm{T}$ cell restriction specificity, function and responsiveness, Adv. Immunol., 27 (1979) 51-75. 